\title{
PANTIES USAGE: FEEL COMFORTABLE OR SEXY?
}

\author{
Marina Anderle Giongo ${ }^{1}$ \\ Júlio Carlos de Souza Van Der Linden ${ }^{2}$ \\ Maurício Moreira e Silva Bernardes ${ }^{3}$
}




\section{Abstract}

This study aimed to investigate women's motivations for panties usage. By means of a survey with 348 women, comfort perception versus appearance evaluation were analyzed, through an behavioral approach. The analysis involved a clustering of primary data and crosstables among clusters. K-Means Cluster Analysis and Pearson's Chi-square Tests by Crosstables were applied. Results indicated that daring women tend to be extroverted and value psychological comfort; conservative women tend to be introverted and value psychological comfort; moderate women tend to be contextual in usage and does not prioritize any comfort dimension.

Key-words: Comfort perception; appearance evaluation; behavioral profiles; panties usage. 


\section{Introduction}

The use of panties is strongly related to women personality. Women have panties preference based upon esthetic or functional expectations. Some women have trouble in finding comfortable panties when they want to feel sexy and fashionable. Otherwise, some women feel constrained when using sexy panties and prefer to use panties that hide undesirable parts of the body, or that make her feel secure. Inappropriate panties design may lead to discomfort and may lost the preference of consumers, while the proper design of panties, combining a desirable look with characteristics to improve comfort perception could enchant consumers. So, understanding the preferences of women is essential to improve panties design.

How to get a good fit in apparel is a huge concern for many researches in the aim to ensure user comfort and better appearance, since there are many studies about that (Fan et al, 2004; Fan et al, 2007; Grogan et al, 2013; Labat and Delong, 1990; Paff Ogle et al, 2014; Vinué et al, 2014; $\mathrm{Yu}, 2011)$. Otherwise, some authors analyzes the satisfaction with clothes from the emotional perspective, mainly related to body image, social aspects, and self-realization (Kamalha et al, 2013; Norton et al, 2013; Rudd \& Lennon, 2000; Tiggemann, 2012; Tsaousi \& Brewis, 2013; Chattaraman \& Rudd, 2006).

Women with lower body satisfaction are less satisfied with the fit of garment, generally. Self confidence, comfort and level of concealment are strongly related to perceived fit, sizing and size identity in clothing. Body confidence and body cathexis - satisfaction with the parts and the whole body - can be affected since a particular garment can made women feel better and more confident about their bodies, when the fit is good and hide the parts disliked of the body (Fan et al, 2004; Fan et al, 2007; Grogan et al, 2013). To Chattaraman \& Rudd (2006), the lower are the body image, the greater has to be the clothing to covering better the body.

Comfort is also affected from wearers' attitudes, norms and beliefs. About the psychological aspect, comfort is affected by roles, values and social aspects of individuals, that addresses internal self-consciousness, value of life and how to satisfying oneself within available choices. In a more sociological approach, body image, personality, values or beliefs, personal interests and awareness among others interfere in comfort perception. Besides, garment attributes like style, texture, esthetics , fashion, suitability, design and color influences the comfort perception (Kamalha et al, 2013; Norton et al, 2013; Wages, 1974). It is important to maintain an affirmative self-image to perceived quality of life, as attractiveness has been viewed as a means to gain access to the power in a male world (Rudd \& Lennon, 2000).

As comfort is not naturally attained, but is a result of evaluated com- 
bination of the wearer - five senses, history and state; environment and clothing attributes. Fulfilling all the aspects of comfort is hard to achieve, so a better attempt has to be done to reach an optimal combined comfort perception. Furthermore, behaviors of individuals are contextual and depend on their comfort in diverse environments and social scenarios (Maldonado, 2011; Norton et al, 2013; Van der Linden, 2003, 2004; Vink, 2002, 2004; Vink et al 2004; Vink \& Hallbeck, 2012).

Moreover, if fashion is a way to communicate identity, underwear choices reveals the deep of individuals' identity. Individuals perceive clothing as a way to establish and validate identity, as an expression of selfworth and an emotional response to self-evaluation and related to body image and body cathexis. The choice of lingerie reflects and stimulates diverse feelings depending on the occasion, forming the woman identity and becoming part of her identity expression. According to Paff Ogle et al (2014) findings, only the types of underwear that make women feel special are called lingerie. So, the consumer behavior of lingerie can be strongly related to identity and behavior of women, as underwear are used to construct and reconstruct various feminine identities, including professional, mother and sexual partner (Paff Ogle et al, 2014; Tsaosi \& Brewis, 2013).

Tiggemann (2012) and Tsaosi \& Brewis (2013) findings brought two concepts that can explain some women behaviors about panties usage. Respectively, bodywork and self-objectification. Bodywork is the way people transform their body from natural to cultural, according to society expectations, how individuals present themselves as acceptable subjects in everyday life. So, underwear has a huge importance to women appearance, since it is a base for outwear appearance and generate sensations of being in comfort in one's own skin, self-confidence and sex appeal. Even as self-objectification that occur when women and girls come to view themselves in objectified condition, as they internalize an observer's perspective. To Tiggemann, comfort is more related to how the body feels and the self-objectification is the opposite of it, when the appearance matters more in clothing (Tiggemann, 2012; Tsaosi \& Brewis, 2013).

To Van der Linden (2004), the orientation that people have related to comfort should be considered, that could be related to pleasure - when the pleasure emotion increase comfort perception; or to integrity preservation - when comfort perception could be inhibited by perception of risk, decreasing also the perception of comfort and appearance. For the author, the behavior of use could be explained from the hedonic dimension and from four types of pleasure stated by Tiger (1992): physical, psychological, sociological and ideological. So, the use of panties that seems to be uncomfortable can be explained by the psychological pleasure, as the refuse to use the same model can be related to physical pleasure.

Also, discomfort can provoke a positive effect, because sometimes it is socially accepted to feel bad, so the individual begins certain behaviors 
in the aim to feel the sensation that is supposed to feel (Cadilha, 2010). This idea justifies the behavioral of women that use comfortable panties only in some occasions, only when she was not with her boyfriend, as they declare in a previous study (Giongo, 2010), when they are supposed to be sexy, it is acceptable to feel uncomfortable intrinsically.

Panties comfort is a very important issue for apparel industry, as it affects customer satisfaction. Apparel industry is growing quickly in Brazilian market, and the sector of intimal apparel grew up 33\% in the last 4 years. This sector has an important role in the whole fashion industry in Brazil, as it hire more than 180 thousand of people and is constituted by 3.3 thousand licensed enterprises (IEMI, 2015). A biannual research about the consumer behavior of various sectors shown that for the lingerie the majority of female consumers are young from 25 to 34 years old $(30,6 \%$ of 1100 respondents) and constituted the social class $C(62,1 \%)$. For the majority of respondents the principal requirement is comfort $(70,8 \%)$, followed by practicality (related to basics; $25,3 \%$ ) for everyday use. Nevertheless, lingerie also has to be sensual $(22,7 \%)$ and romantic $(11,2 \%)$ in same occasions. About the purchase motive, reasons related to emotion count $68,3 \%$ of the sample. According to the responsible for the research, lingerie has its prices and sales driven by level of enchantment they achieve with consumers (IEMI, 2015). Emotion has an important role in the understanding of panties preference, and emotion in products and design is an important field of research (Desmet, 2002, 2003; Desmet \& Hekkert, 2002; Green \& Jordan, 2004; Jordan, 2002).

Aiming to contribute to the development of design guidelines for Brazilian market, a research was developed, that addressed issues related to comfort perception, appearance evaluation and problems in use of panties (Giongo, 2012). In this research, comfort are considered as an affective state, multidimensional - only physical and psychological dimensions, which can be perceived by individuals between the completely uncomfortable to completely comfortable. As a basis for the construction of research instrument, the methods used were Van der Linden (2004) and Wages (1974).

In this paper a behavioral perspective of our results (Giongo, 2012) was presented, that concern to human factors field. It comprises an evaluation of factors involved in comfort perception of panties, according to different female behavioral profiles. The sample consisted of women, all of them undergraduate students, from two universities located in the south of Brazil, one private and one public, from diverse knowledge areas. Instead this research focused in young women (all of them are undergraduate students), it is supposed that comfort in clothing - and specially panties - is an important issue from tweens to older women, as there are some studies about them (Lee et al, 2012; Paff Ogle et al, 2013) and this research could be replicated to these age too. 


\section{Methods}

\subsection{Subjects}

The population consisted in undergraduate women from two universities from metropolitan region of Porto Alegre/RS, located in the south region of Brazil. One private institution and one public were chosen, to equalize variables about socioeconomic aspects, to further enable diversity of personal orientations, due to diversity of knowledge areas of the courses offered. The research reached 347 respondents and most of the sample $(94,4 \%)$ is young, from 17 to 34 years.

\subsection{Types of panties analyzed}

In order to control some variables in the research, six models of panties were defined and nominated, based on best sellers in Brazilian market, to base some evaluations in the questionnaire applied to the sample.

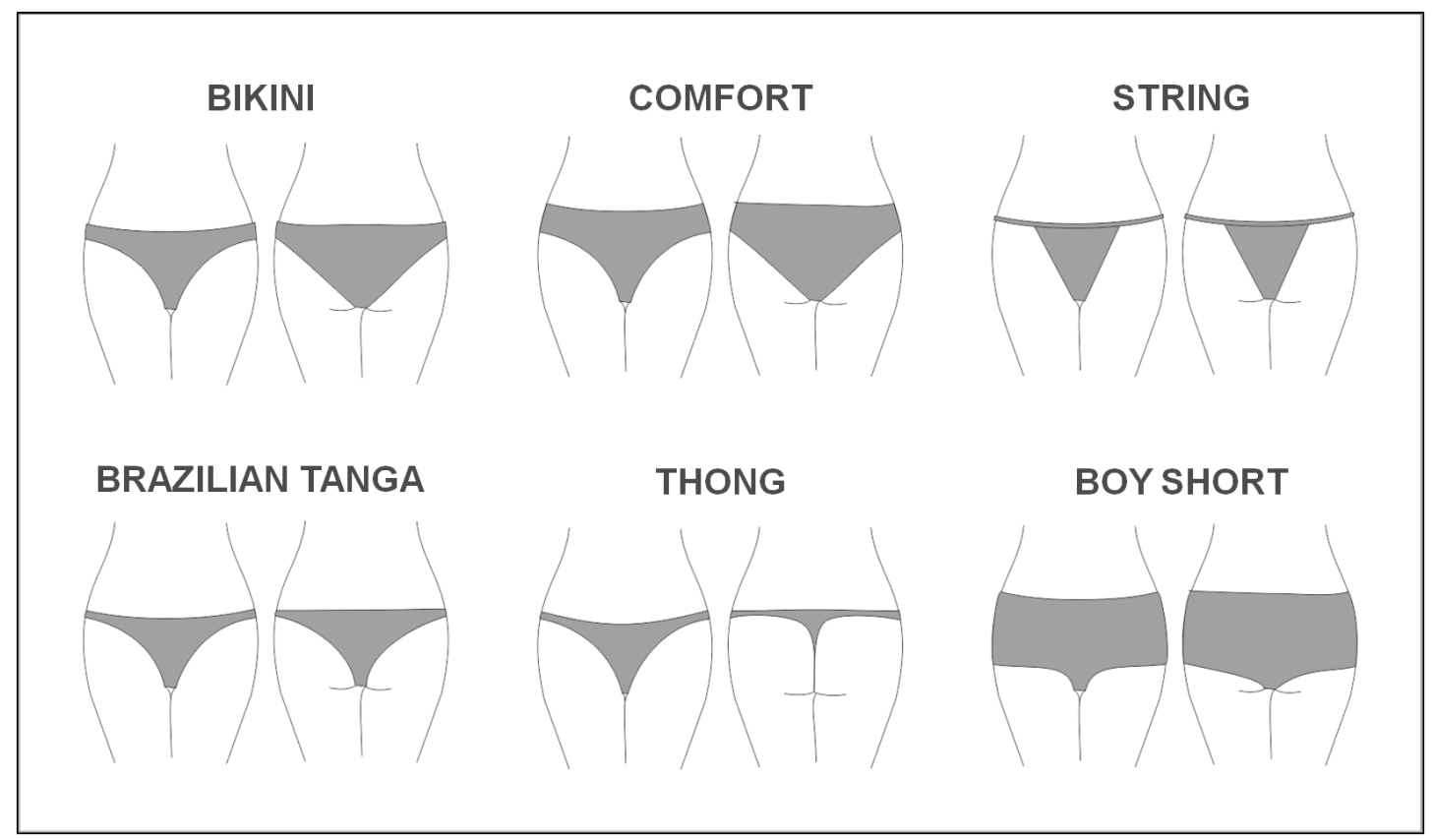

Figure 1 - models of panties analyzed

Source: from the authors

The six models were parameterized and modeled from basic panties pattern, according to the Brazilian panties characteristics:

a) Bikini $-10 \mathrm{~cm}$ below waistline, $4 \mathrm{~cm}$ on the side, $2 \mathrm{~cm}$ to $3 \mathrm{~cm}$ on the back cuts;

b) Comfort $-8 \mathrm{~cm}$ below the waistline, $4 \mathrm{~cm}$ to $6 \mathrm{~cm}$ on the side, front cuts $2 \mathrm{~cm}$ to $3 \mathrm{~cm}$ more open than basic.

c) String - stretch stripes on side or whole waistline of $2 \mathrm{~cm}$ in 
maximum, front and back patterns composed by triangles of $10 \mathrm{~cm}$ to $15 \mathrm{~cm}$.

d) Brazilian Tanga $-10 \mathrm{~cm}$ below waistline, $2 \mathrm{~cm}$ to $3 \mathrm{~cm}$ on sides, $3 \mathrm{~cm}$ to $5 \mathrm{~cm}$ on the back cuts

e) Thong $-3 \mathrm{~cm}$ to $4 \mathrm{~cm}$ crotch, $1 \mathrm{~cm}$ to $4 \mathrm{~cm}$ on the side, big open cut on back, forms a $1 \mathrm{~cm}$ to $3 \mathrm{~cm}$ strip on back.

f) Boyshort $-6 \mathrm{~cm}$ to $8 \mathrm{~cm}$ below the waistline, $6 \mathrm{~cm}$ to $15 \mathrm{~cm}$ on the side, cuts are downgraded.

Only the images of panties were shown to respondents, so they evaluated each panties by its silhouette. Variables like fabric, color, or other style elements are not considered.

\subsection{Questionnaire}

To assess the factors involved in panties comfort perception, a questionnaire, based on Perception of Comfort and Risk Model, proposed by Van der Linden (2004); on methodology developed by Wages (1974) to measure comfort in clothing and in a previous study of perception of comfort in panties (Giongo, 2010) were constructed. The questions about behavioral and psychological aspects are based on Van der Linden (2004) and Wages (1974).

Van der Linden (2004) proposed a classification for what he called dominant references, which is the search for pleasure - as the importance of appearance; and the escape of pain - as the preservation of the integrity. These orientations can be used to evaluate the behavioral profile of users, related to their relations to products usage, which can vary between optimist and pessimist. The author used some questions about concepts and behaviors, in enunciates with situations related to use of female shoes, which the respondents haves to indicate their level of accordance. The responses can be used to classify the respondents in their orientation. Wages (1974) used a similar method, to identify behavioral profiles related to clothes, that she nominated extroverted and introverted, also secure and insecure. The author divided the comfort in three aspects: physical (1), related to hot, cold, looseness, firmness, in the use of clothes; psychosocial (2), related to wellness in social environments and workplaces; and psychological (3), related to mind stability. To her, some people emphasize the psychological aspect of comfort, while other emphasizes the physical aspect.

\subsection{Statistical analysis}

As the sample was a non-normal curve, to analyze the data, non-parametric statistical tests were applied, through the software Statistical Package for Social Science in its 18th version (SPSS18). First, the data was organized into variables and then were recoded them into numbers to 
tabulate and analyze through frequency tables. As the answers for the questions were made by a Likert-type Scale, at first the values were submitted to a non-hierarchic K-means cluster analysis, a test that organizes the answers in groups by similarity to make a better analysis. Clusters analysis improves the homogeneity between variables into the clusters and improves the heterogeneity between the clusters.

At the second step, the Crosstabs with Pearson's Chi-square test was ran, to verify the correlation between the variables. The crosstab was chosen due to its ease of interpretation and clarity of the information presented, besides it helps to expose a complex phenomenon, better than a multivariate analysis. The Pearson's Chi-square was chosen to test the statistical significance between the answers of the sample.

\section{Results and Discussion}

Results and discussion of each question, and analysis between variables are presented in this section.

\subsection{The use of panties}

The question regarding the use of panties addressed the frequency that participants use each type of panties. The results were tabulated and the frequencies of responses were presented in the Table 1. To this sample, the models most used (frequently; daily) are bikini (A) and tanga (D). The models less used (rarely; never) are thong (E) and boy short (F).

\begin{tabular}{|c|c|c|c|c|c|c|}
\hline \multicolumn{7}{|c|}{ FREQUENCY OF USE } \\
\hline & & never & rarely & eventually & frequently & daily \\
\hline BIKINI & $\mathrm{N}$ & 43 & 44 & 54 & 108 & 93 \\
\hline & $\%$ & 12,4 & 12,7 & 15,6 & 31,1 & 26,8 \\
\hline OMFORT & $\mathrm{N}$ & 98 & 54 & 53 & 72 & 65 \\
\hline & $\%$ & 28,2 & 15,6 & 15,3 & 20,7 & 18,7 \\
\hline STRING & $\mathrm{N}$ & 85 & 52 & 62 & 85 & 58 \\
\hline & $\%$ & 24,5 & 15,0 & 17,9 & 24,5 & 16,7 \\
\hline BRAZILIAN & $\mathrm{N}$ & 28 & 42 & 65 & 122 & 82 \\
\hline D & & 8,1 & 12,1 & 18,7 & 35,2 & 23,6 \\
\hline HONG & $\mathrm{N}$ & 144 & 52 & 35 & 68 & 44 \\
\hline & $\%$ & 41,5 & 15,0 & 10,1 & 19,6 & 12,7 \\
\hline BOYSHORT & $\mathrm{N}$ & 203 & 72 & 33 & 25 & 10 \\
\hline & 0 & 58,5 & 20,7 & 9,5 & 7,2 & 2,9 \\
\hline
\end{tabular}


Cluster analysis of frequency of use lead to a 3 clusters solution. The decision for this solution was made because it generated groups with better sample distribution and also better analysis possibility. Based on these groups, 3 profiles of the panties usage were established, shown in the Table 2.

Table 2 - Groups by panties usage profile

\begin{tabular}{|c|c|c|c|c|c|c|}
\hline & BIKINI & COMFORT & STRING & BRAZILIAN & THONG & BOYSHORT \\
\hline DARING & 2 & 1 & 3 & 4 & 4 & 1 \\
\hline MODERATE & 4 & 3 & 3 & 4 & 2 & 2 \\
\hline $\begin{array}{c}\text { CONSERVAT } \\
\text { IVE }\end{array}$ & 4 & 4 & 2 & 3 & 1 & 2 \\
\hline \multicolumn{7}{|c|}{$1=$ never $2=$ rarely $3=$ eventually $4=$ frequently $5=$ daily } \\
\hline
\end{tabular}

Source: authors

The first group was nominated as 'daring', because the most frequently used models are 'Brazilian tanga' and 'thong', the smallest ones, while the less used are the biggest ones, 'comfort' and 'boyshort'. The second group was nominated as 'moderate' considering that the most used models 'bikini and 'Brazilian tanga' are, the middle in terms of concealment and sensuality and these models are in. Finally, the third group was called 'conservative' because the individuals tend to never use the 'thong', the sexiest one, and use frequently the models 'bikini' and 'comfort'.

\subsection{Behavioral profile}

To identify what are defined as the behavioral profile, a question that presents phrases related to use of panties was developed. The level of agreement with each phrase indicated an inclination to one behavior. The responses were submitted to a cluster analysis, forming three groups: introverted, contextual and extroverted. These groups have been nominated based on Wages (1974) and Van der Linden (2004). Table 3 shows the responses that most differentiate and lead the groups' designation. The introverted woman is the most concerned with herself, her integrity; the contextual profile is the woman that are conditioned to a situation, a context of use; while the extroverted women are the group that are turn to others, to society. 


\begin{tabular}{|c|c|c|c|}
\hline & Introverted & Contextual & Extroverted \\
\hline $\begin{array}{c}\text { If a panties is very attractive to me, but causes physic } \\
\text { discomfort, I use it even so }\end{array}$ & $\begin{array}{c}-- \\
\text { STRONGLY } \\
\text { DISAGREE }\end{array}$ & DISAGREE & \\
\hline I give up comfort to feel more beautiful and sexy & DISAGREE & DISAGREE & \\
\hline $\begin{array}{c}\text { It is important to me to use clothes, include panties, that } \\
\text { are fashionable }\end{array}$ & DISAGREE & DISAGREE & \\
\hline $\begin{array}{l}\text { It is important to me that my clothes, include my } \\
\text { panties, create good impression to other people }\end{array}$ & & & 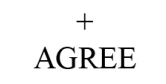 \\
\hline $\begin{array}{l}\text { In special occasions, i give up comfort to use a } \\
\text { beautiful and sexy panties. }\end{array}$ & DISAGREE & 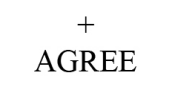 & $\stackrel{+}{+}+\frac{+}{A G R E E}$ \\
\hline $\begin{array}{l}\text { It is more important that a pantie is suitable to my body } \\
\text { type, than it be beautiful or sexy }\end{array}$ & 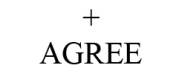 & 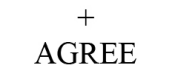 & \\
\hline I prefer a comfortable panties, even if not sexy & $\stackrel{+}{+}+\frac{+}{A G R E E}$ & $\stackrel{+}{+}+\frac{1}{A G R E E}$ & \\
\hline I like discrete panties, that are inconspicuous. & 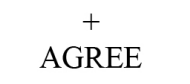 & & DISAGREE \\
\hline I feel constrained with a sensual panties. & & DISAGREE & DISAGREE \\
\hline
\end{tabular}

Table 3 - Behavioral profile of sample: introverted; extroverted; contextual.

Source: authors

For the introverted profile, the reference was the phrase 'If panties are very attractive to me, but causes physic discomfort, I use it even so', that received the answer 'strongly disagree'. As well as agree with the phrase 'I like discrete panties, that are inconspicuous'. These women concern more about themselves than others, they care about their integrity and do not mind so much with society.

The profile of extroverted women answered that agree with the phrases 'It is important to me that my clothes, include my panties, create good impression to other people' and 'In special occasions, I give up comfort to use a beautiful and sexy panties'. Even as they disagree with the phrases 'I like discrete panties that are inconspicuous.' and 'I feel constrained with a sensual panties'. These responses indicate a strong pursuit of pleasure and concern for others.

The women in the middle group were nominated contextual, because their behavioral seems to be leaded by the situation. They disagree with 'I feel constrained with a sensual panties', whereas agree that 'In special occasions, I give up comfort to use a beautiful and sexy panties'.

\subsection{Comfort Perception}

Based on the silhouette of the panties studied and beyond the authors researched, the research consider that panties that cover the body anatomically is more balanced between physical and psychological dimensions of comfort that another that cover too little or too much. So, in this question the perception of comfort of respondents was investigated. 


\begin{tabular}{|c|c|c|c|c|c|c|}
\hline \multicolumn{7}{|c|}{ Comfort in use } \\
\hline & & $\begin{array}{c}\text { Very } \\
\text { uncomfortable }\end{array}$ & uncomfortable & Indiferent & comfortable & $\begin{array}{c}\text { Very } \\
\text { comfortable }\end{array}$ \\
\hline BIKINI & $\mathrm{N}$ & 15 & 19 & 53 & 140 & 115 \\
\hline & $\%$ & 4,3 & 5,5 & 15,3 & 40,3 & 33,1 \\
\hline COMFORT & $\mathrm{N}$ & 12 & 39 & 67 & 118 & 102 \\
\hline & $\%$ & 3,5 & 11,2 & 19,3 & 34,0 & 29,4 \\
\hline STRING & $\mathrm{N}$ & 37 & 92 & 71 & 102 & 38 \\
\hline & $\%$ & 10,7 & 26,5 & 20,5 & 29,4 & 11,0 \\
\hline BRAZILIAN TANGA & $\mathrm{N}$ & 13 & 41 & 82 & 133 & 71 \\
\hline & $\%$ & 3,7 & 11,8 & 23,6 & 38,3 & 20,5 \\
\hline THONG & $\mathrm{N}$ & 120 & 96 & 45 & 52 & 26 \\
\hline & $\%$ & 34,6 & 27,7 & 13,0 & 15,0 & 7,5 \\
\hline BOYSHORT & $\mathrm{N}$ & 59 & 70 & 67 & 60 & 80 \\
\hline & $\%$ & 17,0 & 20,2 & 19,3 & 17,3 & 23,1 \\
\hline
\end{tabular}

Source: authors

Through the frequency of responses, it is possible to verify that the models 'bikini', 'comfort' and 'Brazilian tanga' were mostly perceived as comfortable, while the model 'thong' was mainly perceived as uncomfortable, which reinforced our assumption. The responses were submitted to a cluster analysis and the 3 clusters solution was chosen, designated as 'psychological comfort (pleasure)'; 'physical and psychological comfort' and 'physical comfort', according to our understanding of what comfort dimension could be predominant to each cluster.

Table 5 - Groups by comfort perception

\begin{tabular}{lcccccc}
\hline & 2 & 3 & 3 & 4 & 3 \\
\hline $\begin{array}{c}\text { Psychological } \\
\text { comfort } \\
\text { (pleasure) }\end{array}$ & 2 & 3 & 4 & 4 & 3 & 2 \\
\hline $\begin{array}{c}\text { Physical and } \\
\text { psychological } \\
\text { comfort }\end{array}$ & 4 & 4 & 2 & 3 & 2 & 4 \\
\hline $\begin{array}{l}\text { Physical comfort } \\
\text { 1= Very uncomfortable } 2=\text { uncomfortable 3=indiferent } 4=\text { comfortable 5= Very comfortable }\end{array}$ \\
\hline
\end{tabular}


Then, the group 'psychological comfort (pleasure)' is the one which has the comfort perception affected mainly by psychological dimension, pursuit of pleasure, which justifies the response 'comfortable' to model 'thong' while 'bikini' and 'comfort' are marked as 'uncomfortable'. The group nominated 'physical and psychological comfort' cover the women that answered 'comfortable' to models 'bikini, 'string', and 'Brazilian tanga', which are in the middle of coverage and sensuality, which indicates that these women combine these two dimensions of comfort, with a leaning to social dimension of comfort proposed by Wages (1974). Finally, the cluster that responded 'comfortable' to models 'bikini', 'comfort' and 'boyshort' were called 'physical comfort', since these models have a good concealment, which indicates an inclination to physical dimension of comfort.

\subsection{Appearance Evaluation}

This question addresses an evaluation of appearance of the panties. The participants had to answer the level of pleasure of each panties presented, as shown in Table 6 . The most pleasant models are 'bikini', 'string' and 'Brazilian tanga'. To the sample, the most unpleasant model is the 'boyshort'.

Table 6 - Sample frequency to appearance evaluation of panties

\begin{tabular}{|c|c|c|c|c|c|c|}
\hline \multicolumn{7}{|c|}{ APPEARANCE OF PANTIES } \\
\hline & & $\begin{array}{c}\text { Very } \\
\text { unpleasant }\end{array}$ & unpleasant & Indiferent & pleasant & Very pleasant \\
\hline BIKINI & $\mathrm{N}$ & 11 & 44 & 95 & 145 & 49 \\
\hline & $\%$ & 3,2 & 12,7 & 27,4 & 41,8 & 14,1 \\
\hline COMFORT & $\mathrm{N}$ & 19 & 93 & 108 & 98 & 23 \\
\hline & $\%$ & 5,5 & 26,8 & 31,1 & 28,2 & 6,6 \\
\hline STRING & $\mathrm{N}$ & 21 & 51 & 73 & 141 & 56 \\
\hline & $\%$ & 6,1 & 14,7 & 21,0 & 40,6 & 16,1 \\
\hline $\begin{array}{c}\text { BRAZILIAN } \\
\text { TANGA }\end{array}$ & $\mathrm{N}$ & 6 & 15 & 50 & 194 & 70 \\
\hline & $\%$ & 1,7 & 4,3 & 14,4 & 55,9 & 20,2 \\
\hline THONG & $\mathrm{N}$ & 62 & 61 & 51 & 95 & 72 \\
\hline & $\%$ & 17,9 & 17,6 & 14,7 & 27,4 & 20,7 \\
\hline BOYSHORT & $\mathrm{N}$ & 136 & 107 & 49 & 39 & 14 \\
\hline & $\%$ & 39,2 & 30,8 & 14,1 & 11,2 & 4,0 \\
\hline
\end{tabular}

To this question, a cluster analysis was made and divided into 3 groups, as shown in Table 7. As the prominent responses are the 'unpleasant', the groups were designated by their rejection to each model of panties. 
Table 7 - Groups by appearance evaluation

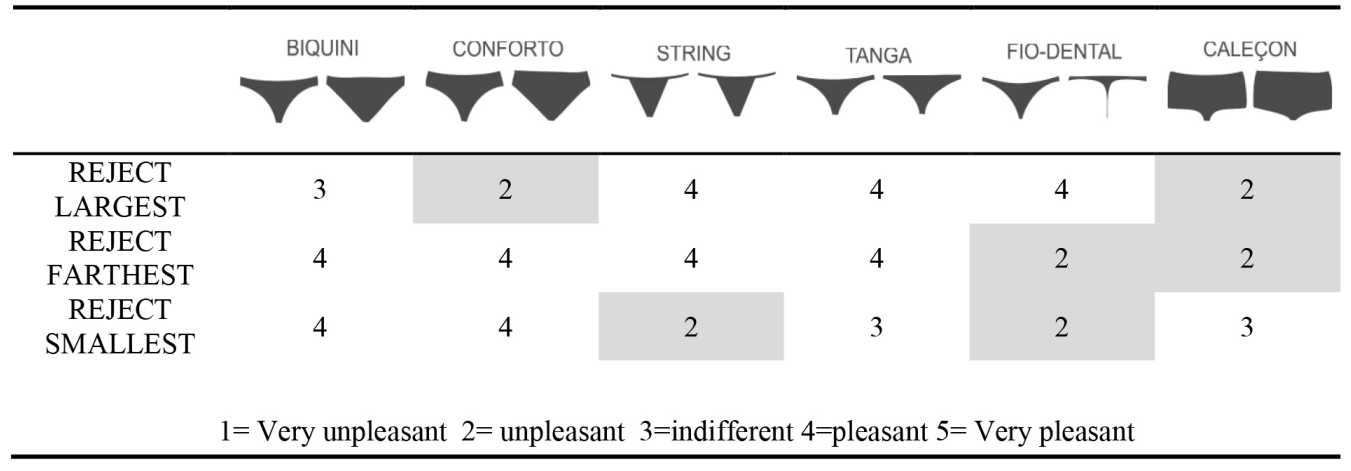

Source: authors

The first group was called 'reject the largest', as they answer 'unpleasant' to appearance of models 'comfort' and 'boyshort', that most cover the body. The cluster 'reject farthest' evaluate the appearance of models 'thong' and 'boyshort' as unpleasant, which are respectively the smallest and the largest one, and are supposed to be more balanced. Lastly, the group named 'reject smallest' classified the appearance of models 'string' and 'thong' as unpleasant, what are the models that most reveal the body.

\subsection{Dimension of Comfort}

This question investigated the responses to some comfort descriptors elicited in a previous survey applied in the main research (Giongo, 2012). Participants were asked to respond about the level of improvement of comfort or discomfort to each descriptor. The sample frequency is shown in Table 8.

Table 8 - Sample frequency to answers to dimension of comfort

\begin{tabular}{|c|c|c|c|c|c|c|}
\hline Wear panties... & $\begin{array}{c}\text { greatly } \\
\text { increases } \\
\text { discomfort }\end{array}$ & $\begin{array}{l}\text { increases } \\
\text { discomfort }\end{array}$ & indifferent & $\begin{array}{l}\text { increases } \\
\text { comfort }\end{array}$ & $\begin{array}{l}\text { greatly } \\
\text { increases } \\
\text { comfort }\end{array}$ & Total \\
\hline that fits to the body & 1 & 4 & 20 & 168 & 145 & 338 \\
\hline beautiful & 0 & 3 & 171 & 122 & 37 & 333 \\
\hline $\begin{array}{l}\text { with details (panels, laces, } \\
\text { applications, color mixing, ...) }\end{array}$ & 14 & 93 & 179 & 40 & 13 & 339 \\
\hline with elastic bands & 24 & 120 & 107 & 70 & 15 & 336 \\
\hline with narrow side & 49 & 144 & 71 & 49 & 19 & 332 \\
\hline with wide side & 14 & 50 & 87 & 150 & 38 & 339 \\
\hline with few seams & 2 & 6 & 51 & 162 & 117 & 338 \\
\hline high waist & 26 & 90 & 96 & 94 & 26 & 332 \\
\hline low waist & 31 & 119 & 117 & 62 & 11 & 340 \\
\hline of lace & 25 & 100 & 159 & 43 & 8 & 335 \\
\hline of hypoallergenic fabric & 0 & 3 & 121 & 141 & 69 & 334 \\
\hline of stretch fabric & 5 & 30 & 97 & 160 & 41 & 333 \\
\hline of firm fabric & 11 & 69 & 100 & 122 & 34 & 336 \\
\hline of lightweight fabric & 2 & 9 & 50 & 187 & 91 & 339 \\
\hline of soft fabric & 1 & 2 & 24 & 195 & 116 & 338 \\
\hline of natural fabric (cotton, rayon, ...) & 3 & 3 & 52 & 162 & 115 & 335 \\
\hline $\begin{array}{l}\text { of synthetic fabric (microfiber, } \\
\text { nylon, lycra, ...) }\end{array}$ & 17 & 86 & 118 & 86 & 33 & 340 \\
\hline
\end{tabular}




\begin{tabular}{ccccccc} 
of breathable fabric & 1 & 4 & 83 & 162 & 86 & 336 \\
delicate & 1 & 12 & 146 & 119 & 59 & 337 \\
printed & 6 & 8 & 273 & 34 & 13 & 334 \\
big & 42 & 108 & 119 & 60 & 9 & 338 \\
plain & 4 & 4 & 228 & 74 & 24 & 334 \\
small & 53 & 137 & 87 & 45 & 12 & 334 \\
that tightens & 203 & 112 & 15 & 7 & 2 & 339 \\
that covers the buttocks & 57 & 98 & 102 & 67 & 14 & 338 \\
which marks under clothing & 161 & 146 & 25 & 4 & 0 & 336 \\
which marks the body & 162 & 133 & 23 & 15 & 2 & 335 \\
that models the body & 11 & 21 & 79 & 154 & 71 & 336 \\
seamless & 0 & 2 & 57 & 163 & 113 & 335 \\
sensual & 9 & 31 & 171 & 82 & 40 & 333 \\
cut out at the buttocks & 66 & 99 & 74 & 60 & 33 & 332 \\
that I do not realize that I am using & 2 & 8 & 36 & 99 & 196 & 341 \\
\hline
\end{tabular}

In this question only 2 groups were possible to made, because of the homogeneity of the clusters size, as shown in Table 9, which shows the descriptors separately according to the comfort or discomfort.

Table 9 - Clusters by dimension of comfort

\begin{tabular}{|c|c|c|c|}
\hline & Wear panties. & $\begin{array}{l}\text { Group } 1 \text { - values } \\
\text { psychological } \\
\text { comfort }\end{array}$ & $\begin{array}{l}\text { Group } 2 \text { - values } \\
\text { physical comfort }\end{array}$ \\
\hline \multirow{12}{*}{$\mathrm{D}$} & with details (panels, laces, applications, color mixing, ...) & 3 & 3 \\
\hline & with elastic bands & 3 & 3 \\
\hline & with narrow side & 3 & 2 \\
\hline & high waist & 3 & 3 \\
\hline & low waist & 3 & 2 \\
\hline & of lace & 3 & 3 \\
\hline & synthetic fabric (microfiber, nylon, lycra, ...) & 3 & 3 \\
\hline & small & 3 & 2 \\
\hline & that tightens & 1 & 1 \\
\hline & which marks under clothing & 1 & 2 \\
\hline & which marks the body & 2 & 2 \\
\hline & cut out at the buttocks & 4 & 2 \\
\hline \multirow{21}{*}{$\mathrm{C}$} & that fits to the body & 5 & 4 \\
\hline & beautiful & 4 & 3 \\
\hline & with wide side & 3 & 4 \\
\hline & with few seams & 4 & 4 \\
\hline & of hypoallergenic fabric & 4 & 4 \\
\hline & of stretch fabric & 4 & 4 \\
\hline & of firm fabric & 3 & 3 \\
\hline & of lightweight fabric & 4 & 4 \\
\hline & of soft fabric & 4 & 4 \\
\hline & of natural fabric (cotton, rayon, ...) & 4 & 4 \\
\hline & of breathable fabric & 4 & 4 \\
\hline & delicate & 4 & 3 \\
\hline & printed & 3 & 3 \\
\hline & big & 2 & 3 \\
\hline & plain & 3 & 3 \\
\hline & that covers the buttocks & 2 & 3 \\
\hline & that models the body & 4 & 4 \\
\hline & seamless & 4 & 4 \\
\hline & sensual & 4 & 3 \\
\hline & that I do not realize that I am using & 4 & 4 \\
\hline & $\begin{array}{r}=\text { greatly increases discomfort } 2=\text { increases discomfort } 3=\text { ind } \\
\text { increases comfort } \\
C=\text { comfort descriptors } D=\text { discomfo }\end{array}$ & $\begin{array}{l}\text { nt } 4=\text { increases co } \\
\text { criptors }\end{array}$ & ort $5=$ greatly \\
\hline
\end{tabular}

Source: authors 
The first cluster was designated as 'values psychological comfort', because of the positive responses - 'increases comfort' - to the discomfort descriptor 'cut out at the buttocks', as well as negative responses - 'increases discomfort' to the comfort descriptors 'big' and 'that covers the buttocks'. The positive responses to 'beautiful', 'delicate' and 'sensual' indicated a behavioral and a comfort perception mainly psychological, linked to value of appearance and pursuit of pleasure.

The second cluster was nominated as 'values physical comfort' due to the negative responses - increases discomfort - to the discomfort descriptors 'with narrow side', 'low waist', 'small' and 'cut out at the buttocks'. This group tends to be motivated by physical comfort, which is confirmed with the positive response - 'increases comfort' - to the comfort descriptor 'with wide side'.

\subsection{Cross tabulation between clusters}

To better understand the motivation of use of panties, some cross tabulation were performed between the clusters found at the first step of the analysis. This procedure also helped to enhance the reliability of data founded. Pearson's Chi-square tests were performed in cross tabs between use profile and the other variables: behavioral profile, comfort perception, appearance evaluation, and dimension of comfort.

The crossing between usage profile and behavioral profile had three significant associations: daring women tend to be extroverted; moderate women tend to be contextual and conservative women tend to be introverted.

Table 12 - cross tabulation to usage profile $\mathrm{x}$ behavioral profile

\begin{tabular}{ccccc}
\hline \multirow{2}{*}{ Usage profile } & \multicolumn{3}{c}{$\begin{array}{c}\text { Behavioral profile } \\
\text { contextual }\end{array}$} & extroverted \\
\cline { 3 - 5 } daring & Count & 12 & 18 & 64 \\
& Expected count & 22,2 & 39,9 & 31,9 \\
& Adjusted residual & $-3,0$ & $-5,6$ & 8,5 \\
\hline \multirow{3}{*}{ moderate } & Count & 22 & 63 & 30 \\
& Expected count & 27,2 & 48,8 & 39,0 \\
& Adjusted residual & $-1,5$ & 3,4 & $-2,3$ \\
\hline \multirow{3}{*}{ conservative } & Count & 35 & 43 & 5 \\
& Expected count & 19,6 & 35,2 & 28,1 \\
& Adjusted residual & 4,7 & 2,0 & $-6,3$ \\
\hline \multirow{2}{*}{ Total } & Count & 69 & 124 & 99 \\
& Expected count & 69,0 & 124,0 & 99,0 \\
\hline
\end{tabular}

Source: authors

The crossing between usage profile and comfort perception clusters had also three significant associations: daring women tend to perceive comfort through psychological dimension; moderate women tend to perceive comfort through physical and psychological dimension and conservative women tend to perceive comfort through physical dimension. 
Table 10 - cross tabulation to usage profile $\mathrm{x}$ comfort perception clusters

\begin{tabular}{|c|c|c|c|c|}
\hline \multicolumn{2}{|c|}{ Usage profile } & \multicolumn{3}{|c|}{ Comfort perception clusters } \\
\hline & profile & physical comfort & $\begin{array}{c}\text { physical and } \\
\text { psychological } \\
\text { comfort }\end{array}$ & $\begin{array}{c}\text { psychological } \\
\text { comfort (pleasure) }\end{array}$ \\
\hline \multirow{3}{*}{ daring } & Count & 17 & 50 & 37 \\
\hline & Expected count & 50,5 & 38,8 & 14,7 \\
\hline & Adjusted residual & $-4,7$ & 1,8 & 5,8 \\
\hline \multirow{3}{*}{ moderate } & Count & 57 & 65 & 6 \\
\hline & Expected count & 62,2 & 47,7 & 18,1 \\
\hline & Adjusted residual &,- 7 & 2,5 & $-2,8$ \\
\hline \multirow{3}{*}{ conservative } & Count & 81 & 4 & 2 \\
\hline & Expected count & 42,3 & 32,5 & 12,3 \\
\hline & Adjusted residual & 6,0 & $-5,0$ & $-2,9$ \\
\hline \multirow{2}{*}{ Total } & Count & 155 & 119 & 45 \\
\hline & Expected count & 155,0 & 119,0 & 45,0 \\
\hline
\end{tabular}

The cross tabulations between usage profile and appearance evaluation clusters generated three significant associations too: daring women tend to reject largest panties; moderate women tend to reject farthest from standard panties and conservative women tend to reject smallest panties.

Table 11 - cross tabulation to usage profile $\mathrm{x}$ appearance evaluation clusters

\begin{tabular}{ccccc}
\hline \multirow{2}{*}{ Usage profile } & \multicolumn{3}{c}{$\begin{array}{c}\text { Appearance evaluation clusters } \\
\text { reject farthest from } \\
\text { standard }\end{array}$} & reject largest \\
\cline { 3 - 5 } daring & reject smallest & 17 & 86 \\
& Count & 5 & 43,5 & 43,9 \\
& Expected count & 20,6 & $-4,0$ & 6,4 \\
& Adjusted residual & $-3,4$ & 72 & 41 \\
\multirow{3}{*}{ moderate } & Count & 14 & 51,2 & 51,6 \\
& Expected count & 24,2 & 2,9 & $-1,5$ \\
\hline \multirow{3}{*}{ conservative } & Adjusted residual & $-2,1$ & 40 & 3 \\
& Count & 42 & 34,3 & 34,5 \\
& Expected count & 16,2 & 1,0 & $-5,4$ \\
\hline \multirow{2}{*}{ Total } & Adjusted residual & 6,4 & 129 & 130 \\
& Cxpected count & 61 & 129,0 & 130,0 \\
\hline
\end{tabular}

Source: authors

The last cross tabulation was between usage profile and dimension of comfort clusters and generated only two significant associations: daring women tend to value psychological comfort and conservative women tend to value physical comfort. 
Table 13 - cross tabulation to usage profile $\mathrm{x}$ dimension of comfort clusters

\begin{tabular}{|c|c|c|c|}
\hline \multirow{2}{*}{\multicolumn{2}{|c|}{ Usage profile }} & \multicolumn{2}{|c|}{ Dimension of comfort clusters } \\
\hline & & values psychological comfort & values physical comfort \\
\hline \multirow{3}{*}{ daring } & Count & 56 & 24 \\
\hline & Expected count & 31,6 & 48,4 \\
\hline & Adjusted residual & 6,8 & $-6,8$ \\
\hline \multirow{3}{*}{ moderate } & Count & 33 & 67 \\
\hline & Expected count & 39,5 & 60,5 \\
\hline & Adjusted residual & $-1,7$ & 1,7 \\
\hline \multirow{3}{*}{ conservative } & Count & 9 & 59 \\
\hline & Expected count & 26,9 & 41,1 \\
\hline & Adjusted residual & $-5,2$ & 5,2 \\
\hline \multirow{2}{*}{ Total } & Count & 98 & 150 \\
\hline & Expected count & 98,0 & 150,0 \\
\hline
\end{tabular}

Source: authors

Significant associations between clusters corroborate with the assumption that dominant references are related to the profile of use, in other words, in the choice of panties. The Figure 2 shows all the relations between usage profile and other variables.

\begin{tabular}{|c|c|c|c|c|}
\hline Usage Profile & $\begin{array}{l}\text { Behavioral } \\
\text { Profile }\end{array}$ & $\begin{array}{l}\text { Comfort } \\
\text { Perception }\end{array}$ & $\begin{array}{l}\text { Appearance } \\
\text { Evaluation }\end{array}$ & Dimension of comfort \\
\hline DARING & Extroverted & $\begin{array}{l}\text { Psychological } \\
\text { comfort } \\
\text { (pleasure) }\end{array}$ & Reject largest & $\begin{array}{c}\text { Values psychological } \\
\text { comfort }\end{array}$ \\
\hline MODERATE & Contextual & $\begin{array}{l}\text { Physical and } \\
\text { psychological } \\
\text { comfort }\end{array}$ & Reject farthest & - \\
\hline CONSERVATIVE & Introverted & Physical comfort & Reject smallest & $\begin{array}{l}\text { Values physical } \\
\text { comfort }\end{array}$ \\
\hline
\end{tabular}

Figure 2 - Significant associations between the clusters Source: authors

It is clear with these findings that women have different behavior against panties choice and usage, which is coherent with their perception of comfort, lead to their inclination to a dimension of comfort and their evaluation of panties appearance. All these interactions reflect on the panties usage and depend on their background, their behavior towards society, their concern with others and their dominant reference to pursuit of pleasure or preservation of integrity.

So, the main results are that introverted women tend to value comfort as the physical dimension, be conservative and care less with their appearance than their well-being. Extroverted women tend to value comfort in its psychological dimension, or pursuit of pleasure. They are daring and value their appearance more than their well-being.

\section{Conclusions}

It is well known that women have different profiles and literature has shown that this background could influence the perception of comfort and consequently the 
choice related to products. The assumption that these variables would influence the panties usage was validated by the significant associations between the variables, and this validation through statistical analysis is very important and necessary to systematize the understanding about women behavior in panties choice and use.

For the three usage profiles identified in our research, was found a coherent choice of panties related to comfort and appearance. In each cluster women use to use more frequently the models of panties which they perceive as comfortable and pleasant, and use less frequently the models of panties they perceive as uncomfortable and unpleasant.

The daring woman is extroverted, characterized by the pursuit of pleasure. She values psychological comfort and uses more frequently the models 'Brazilian tanga' and 'thong', which considers pleasant in the appearance, besides perceives the model 'thong' as comfortable. The model 'string' is used eventually and also considered pleasant. On the contrary, the models 'bikini', 'comfort' and 'boyshort', which are considering uncomfortable and unpleasant are used rarely or never.

The moderate woman is contextual, perceives comfort as both psychological and physics dimensions and uses more frequently the models 'bikini' and 'Brazilian tanga', which are perceived as comfortable and evaluated as pleasant, as the models 'comfort' and 'string', which they use eventually. Otherwise, the models rarely used are perceived as uncomfortable and evaluated as unpleasant appearance.

The conservative woman is introverted, characterized by the concern about herself. She values physical dimension of comfort and frequently uses models 'bikini' and 'comfort', which are perceived as comfortable and evaluated as pleasant. The model 'string' is perceived as uncomfortable and evaluated as unpleasant is rarely used by this woman. The model 'thong' is never used by this woman, perceived as uncomfortable and evaluated as unpleasant.

This paper presented an analysis based on the usage profile as a center of the analysis as a dependent variable, by means of a behavioral approach. As a suggestion, another kind of analysis could be made, in the aim to understanding how appearance evaluation and comfort perception are influenced by behavioral profile. In this paper, were not approached the physical characteristics of the sample, which can contribute a lot for the understanding of panties usage. Also, as a suggestion, a further research could be made with different characteristics of sample in this paper, such as another age group, or another region. A comparison study between Brazilian and foreign women would also be interesting.

\section{REFERENCES}

ASHDOWN, S. P., \& DELONG, M. Perception testing of apparel ease variation. Applied Ergonomics, 26(1), 47-54. 1995. doi:10.1016/0003-6870(95)95750-T.

CADILHA, N. M. F. Regulação da satisfação das necessidades de prazer e dor: relações com o bem-estar e distress psicológicos (Satisfaction regulation of pleasure and pain needs: relations among the well-being and psychological distress) [master dissertation]. 2010.

CHATTARAMAN, V., \& RUDD, N. A. Preferences for aesthetic attributes in clothing 
as a function of body image, body cathexis and body size. Clothing and Textiles Research Journal, 24(1), 46-61. 2006.

DESMET, P. A multilayered model of product emotions. The design journal, 6(2), 4-13. 2003.

DESMET, P. M., \& HEKKERT, P. The basis of product emotions. Pleasure with products, beyond usability, 60-68. 2002.

DESMET, P. MA. Designing Emotions (Doctoral dissertation, Doctoral Dissertation. TU Delft, Netherlands). 2002.

EMBACHER, A. Moda e identidade: a construção de um estilo próprio (Fashion and Identity: construction of an own style). Anhembi Morumbi. 1999.

FAN, J., DAI, W., QIAN, X., CHAU, K. P., \& LIU, Q. Effects of shape parameters on the attractiveness of a female body 1, 2. Perceptual and motor skills, 105(1), 117-132. 2007.

FAN, J., YU, W., \& HUNTER, L. Clothing appearance and fit: Science and technology. Elsevier. 2004.

GREEN, W. S., \& JORDAN, P. W. (Eds.). Pleasure with products: Beyond usability. CRC Press. 2003.

GROGAN, S., GILL, S., BROWNBRIDGE, K., KILGARIFF, S., \& WHALLEY, A. Dress fit and body image: A thematic analysis of women's accounts during and after trying on dresses. Body image, 10(3), 380-388. 2013. doi:10.1016/j.bodyim.2013.03.003.

IEMI. Moda Íntima e Meias 2015 (Intimal Apparel and Hosiery 2015). 2015a. Available at <http://www.iemi.com.br/biblioteca/estudos-do-mercado-potencial/moda-intima-e-meias/ > Acesso em 15 mai 2016.

IEMI. Comportamento do Consumidor de Moda Íntima Feminina (Female underwear consumer behavior). 2015b. Available at <http://www.iemi.com.br/biblioteca/ estudos-do-comportamento-de-compra/comportamento-do-consumidor-de-moda -intima-feminina/ > Acesso em 15 mai 2016.

IEMI. Pesquisa de moda íntima pode te ajudar a guiar a empresa (Underwear research can help you to guide your company). 2015c. Available at <http://www.iemi.com. $\mathrm{br} / \mathrm{na}$-midia-pesquisa-de-moda-intima-pode-te-ajudar-a-guiar-a-empresa/> Acesso em 15 mai 2016.

IEMI. Vestidas para matar: mulheres investem cada vez mais em moda íntima (Dressed to kill: women are increasingly investing in underwear). 2015d. Available at <http://www.iemi.com.br/vestidas-para-matar-mulheres-investem-cada-vez-mais -em-moda-intima/> Acesso em 15 mai 2016.

IEMI. Press Release: Em novo estudo, IEMI mostra que emoção é o que determina escolha de moda íntima (In new study IEMI shows that emotion is what determines underwear choice). 2015e. Available at <http://www.iemi.com.br/press-release-em-novo -estudo-iemi-mostra-que-emocao-e-o-que-determina-escolha-de-moda-intima/> Acesso em 15 mai 2016.

JORDAN, P. W. Designing pleasurable products: An introduction to the new human factors. CRC press. 2002.

KAMALHA, E., ZENG, Y., MWASIAGI, J. I., \& KYATUHEIRE, S. The comfort dimension; a review of perception in clothing. Journal of sensory studies,28(6), 423-444. 2013. doi:10.1111/joss.12070.

LEE, H. Y., \& HONG, K. Optimal brassiere wire based on the 3D anthropometric measurements of under breast curve. Applied Ergonomics,38(3), 377-384. 2007. doi:10.1016/j.apergo.2006.03.014.

LEE, Y. A., DAMHORST, M. L., LEE, M. S., KOZAR, J. M., \& Martin, P. (2012). Ol- 
der women's clothing fit and style concerns and their attitudes toward the use of 3D body scanning. Clothing and Textiles Research Journal, 30(2), 102-118. doi:10.1177/0887302X11429741.

MALDONADO, T., \& Cullars, J. The idea of comfort. Design Issues, 35-43. 1991.

MARTINS, S. B. Ergonomics and Fashion: the OIKOS methodology for usability and comfort evaluation in clothing and fashion. Work: A Journal of Prevention, Assessment and Rehabilitation, 41, 6059-6067. doi:10.3233/WOR-2012-1061-6059. 2012.

NORTON, E., HOLLOWAY, I., \& GALVIN, K. Comfort vs risk: a grounded theory about female adolescent behaviorin the sun. Journal of clinical nursing, 23(13-14), 1889-1899. 2014. doi:10.1111/jocn.12481.

PAFF OGLE, J., H. HYLLEGARD, K., \& YAN, R. N. An investigation of mothers' and tween daughters' clothing preferences and purchase intentions toward a prosocial clothing company. Journal of Fashion Marketing and Management, 18(1), 70-84. 2014. doi:10.1108/JFMM-09-2012-0060.

RUDD, N. A., \& LENNON, S. J. Body image and appearance-management behaviors in college women. Clothing and Textiles Research Journal, 18 (3), 152-162. 2000.

TIGGEMANN, M., \& ANDREW, R. Clothing choices, weight, and trait self-objectification. Body image, 9(3), 409-412. 2012. doi:10.1016/j.bodyim.2012.02.003.

TSAOUSI, C., \& BREWIS, J. Are you feeling special today? Underwear and the 'fashioning' of female identity. Culture and Organization, 19(1), 1-21. 2013. doi: 10.1080/14759551.2011.634196

VAN DER LINDEN, Júlio C S. Um modelo descritivo da percepção de conforto e de risco em calçados femininos (A descriptive model of comfort and risk perception of female shoes) [Doctoral dissertation]. Programa de Pós-Graduação em Engenharia de Produção. Porto Alegre: UFRGS). 2004.

VAN DER LINDEN, Júlio C S. O conceito de conforto (The concept of comfort). Revista Tecnologia e Tendências, Novo Hamburgo , v.2, n.2, ano 2 , p. 21-30. 2003.

VINK, P. Comfort. Technische Universiteit Delft (TU Delft). 2002.

VINK, P. (Ed.). Comfort and design: principles and good practice. CRC press. 2004.

VINK, P. P., OVERBEEKE, C. J., \& DESMET, P. M. A. Comfort experience. Ed. P. Vink, 1. 2004.

VINK, P., \& HALLBECK, S. Editorial: Comfort and discomfort studies demonstrate the need for a new model. Applied ergonomics, 43(2), 271-276. 2012.

VINUÉ, G., LEÓN, T., ALEMANY, S., \& AYALA, G. Looking for representative fit models for apparel sizing. Decision Support Systems, 57, 22-33. 2014.doi:10.1016/j. dss.2013.07.007.

WAGES, T. B. The design and development of a measure for comfort in clothing (Doctoral dissertation, Texas Tech University). 1974.

$\mathrm{YU}, \mathrm{W}$. Achieving comfort in intimate apparel. Improving Comfort in Clothing, 427-448. doi:10.1016/B978-1-84569-539-2.50017-X.

\section{Acknowledgements}

To CAPES which financed this research with a master scholarship 